\title{
Farmer innovation system and government intervention: An empirical study of straw utilisation technology development and diffusion in China
}

(A paper submitted to Journal of Cleaner Production)

\author{
Liyan Zhang ${ }^{\mathrm{a}}$ and Bin $\mathrm{Wu}^{\mathrm{b}^{*}}$
}

a. Center for Innovation and Entrepreneurship, Tianjin University of Finance and Economics, Tianjin, China, liyan_zhang_666@163.com

b*. Nottingham University Business School, Nottingham, UK, bin.wu@nottingham.ac.uk (Corresponding author)

\section{ABSTRACT}

In the context of rural sustainability in the developing world, a dilemma facing government intervention is to recognise and properly use local (or indigenous, practical) knowledge. This paper sheds new light on government intervention by introducing a farmer innovation system (FIS), which is initiated by farmer innovator(s) with participation or support from government agencies and other stakeholders for technology improvement and diffusion. In relation to different understandings, attitudes and approaches to farmer innovation, we argue that different government intervention may lead to different project designs and results. The complexity of government intervention in farmer innovation can be seen from an empirical study of the development and diffusion of straw utilisation technology (SUT) in rural China. By analysing and comparing two cases - one successful and one failed - we reveal two types of government intervention, and features and conditions of project success. The major limitation is identified as leaving out other actors such as local business partners and non-government agencies. We suggest a balanced account between farmer innovator(s), government intervention and innovation platform in future research.

Key words: farmer innovation system (FIS), government intervention, straw utilisation technology (SUT), rural China

\section{Introduction}

For rural development, agricultural innovation and environment protection in the developing world, there is a long debate on the nature and role of "state intervention". Having witnessed many human tragedies of the twentieth century (e.g. Great Leap Forward in China, collectivization in Russia, compulsory collectivisation in African countries) caused by government's social engineering schemes, James Scott (1998) views state intervention as a process of extensive control over people and territory which leaves little space for other societal actors to play. Challenging such a dominant approach, nonetheless, there is a call for "beyond the state" $(\mathrm{Li}, 2005)$ or "the return of the state" (Cordoba and Jansen, 2014), to improve infrastructure and public services. A key and unsolved issue facing both 
schools of thought is how to recognise the value of local (traditional, indigenous or practical) knowledge, and identify by what channel or mechanism such knowledge can be integrated into current innovation systems or development programmes which are still overwhelmingly dominated by either governments or professionals (Gupta, 2012; Li, 2005)

This paper attempts to tackle this dilemma by focusing on the interfaces between local knowledge within grassroots innovators and "scientific" knowledge in the formal sector for better using and managing local resources, opportunities and overcoming local challenges. In this regard, farmer innovation system (FIS) is a useful concept for us to observe and analyse the communication, interaction and cooperation between farmer innovator(s), community members, external professionals, government and non-government agencies to improve rural environments and livelihood systems (QUNO, 2015).

In relation to the debate on state intervention, we attempt to examine the role of government intervention in farmer innovation diffusion in order to develop our understanding of the balance and interfaces between top-down government intervention and bottom-up development. The necessity and complexity of government intervention can be illustrated from China practices since its market-oriented reform in the 1980s with mixed results: successes and failures. Compared to a rich body of literature on government intervention on formal agricultural research and extension (Delman, 1991; Sun, et al., 2014; Wang, et al. 2016; Zhu, 2014), only a handful of researchers have paid attention to farmer innovation and government intervention (Gupta, 2012; Wu, 2003; Wu and Pretty, 2004; Wu and Zhang, 2013).

This paper sheds new light on government intervention through a case of Straw Utilization Technology (SUT) development and diffusion. This case is important because China is rich in terms of biomass resources including a variety of straw and agricultural processing residues, such as those of corn, rice, wheat, cotton, and oil-bearing crops. In theory, there is a total of 820 million tons of straw every year, of which approximately 690 million tons are available to collect. Currently, 350 million tons are used as fertilizer, and for animal feed, materials for food (e.g. mushroom plantation) and industrial (e.g. paper manufacturing) production per year, and the remaining 340 million tons can be transferred for the use of energy including biomass power generation, electricity, biogas, biomass fuel and bi-fuel ethanol which is equivalent to an amount of 170 million tons coal (Liu, et al., 2008; SEB, 2012). Regarding the use of straw for energy production, furthermore, only $2.35 \%$ has been used in practice, leaving the vast majority (97.6\%) unused (SEB, 2012).

The complexity of SUT development and diffusion in rural China can be seen from the uneven process in research and application of semi-gasified stoves. Despite its great potential with clear benefits to both local and wider environments, it is difficult for individuals or commercial firms to initiate this process due to the heavy costs of collecting, transporting and storing straw. Government intervention (including financial subsidies) is important not only for farmer innovators to continue to develop and 
improve this technology, but also for other stakeholders, such as agribusiness firms and governmental and non-governmental agencies, to work together with farmer innovators and ensure wide dissemination and adoption.

In the past two decades or so, Chinese government has paid increasing attention to the efficient use of straw resources for the purposes of a cleaner sky, beautiful countryside and reduction of $\mathrm{CO}^{2}$ emissions. A series of government campaigns and policies have been issued to stimulate the development and application of the SUT alongside the administrative prohibition of direct burning in the field (Sinton, et al., 2004; Wang, et al., 2016; Wang and Jiang, 2017). They include the promotion of new technologies such as straw return back to farmland, and straw-based power stations. Despite the above effort, there is a long way for China to go in full use of straw resources.

We consider the development and diffusion of SUT as a process of establishing and maintaining farmer innovation system, referring a process of innovation initiated by farmer innovators with participation or support by government and other stakeholders. Based on narratives of two cases of SUT development and diffusion, in particular, this paper aims to address the following questions: How did farmer innovator(s) initiate a process of SUT development and diffusion? What role have government agencies played in establishing and maintaining a FIS? What are variations of government intervention in terms of approaches and styles, leading to differences in SUT development and innovation diffusion?

This paper is organised as follows. The next section reviews the debates on state intervention and farmer innovation system. It is followed by research design and methodology for our fieldwork. In Section 4, we present two representative cases of government intervention: one successful and another a failure. Based upon empirical evidence, we discuss two types of government intervention, features of each type and the conditions of the successful intervention (Section 5), and draw our conclusion in Section 6.

\section{Literature review: state intervention and the farmer innovation system}

Reflecting the numerous case of failures in national strategies, campaigns or programmes in the twentieth century, the term state intervention has been coined in more or less negative terms and refers to such phenomena in which "[states] construct simplified models of the world that they would like to control and improve, yet improvement schemes fail in proportion to their effectiveness at preventing people from applying the everyday knowledge essential to human well-being" ( $\mathrm{Li}, 2005: 383)$. As social engineering, according to Scott (1998: 4-5), state intervention consists of four elements: 1) "the administrative ordering of nature and society", 2) "a high-modernist ideology" and "legitimacy of science and technology"; 3) "an authoritarian state that is willing and able to use the full weight of its coercive power to bring these high-modernist designs into being", and 4) "a prostrate civil society that 
lacks the capacity to resist these plans". Whilst Scott's theory may be right in explaining why "certain schemes to improve the human condition" failed in planned economies such as Soviet Union and prereformed China, it could hardly reflect or explain the progress made by reformed China and other transitional countries where there is more space for business entrepreneurs, reformists and other nonstate actors who could influence development planning and implementation.

Against the above simplified, unbalanced, and top-down approach to "state-society" or "powerresistance" relationship, there is a call for "beyond the state" or "return of the state" to rebalance between state and non-state stakeholders. Rejecting the claim of the state monopoly, for instance, $\mathrm{Li}$ (2005: 386) emphasises that "many improvement schemes are formed through an assemblage of objectives, knowledge, techniques, and practices of diverse provenance". Along similar lines, Cordoba and Jansen (2014: 482) argue that "state intervention cannot be analysed in isolation but must take into account the state's changing articulations with different forces in civil society, since power-relations within society influence the state and are in turn influenced by state power".

The key characteristics of state intervention, according to Scott (1998: 6), are legibility and simplification, which "exclude the fund of valuable knowledge embodied in local practices". Taking a Greek term mētis, he highlights the value of local or practical knowledge in settings that are "mutable, indeterminant (some facts are unknown), and particular" (Scott, 1998: 316). Whilst the mêtis or local knowledge is necessary to a successful practice, a big challenge facing governmental and development agencies is the "relationship between scientific knowledge and practical knowledge" which is "part of a political struggle for institutional hegemony by experts and their institutions" (ibid: 311). As a result, whether or how to recognise the value of local knowledge, and bring it into development planning and implementation becomes a key for the success or failure of state intervention.

With a focus on the interfaces between local (practical) knowledge and scientific knowledge, perhaps, the literature on farmer innovation, diffusion and systems is most relevant. The term farmer innovation here refers to any technological invention or improvement made by rural people in order to cope with the complexity of local resource, ecological, economic and social conditions (Wu, 2003; Wu and Zhang, 2013). Farmer innovation is emphasised in the process of farmers' communication, interaction and cooperation in the search for, testing and development of new technologies (principles, methods, means, products and know-how) for their livelihood security. More importantly, it draws our attention to the existence and value of "local knowledge" (or traditional, indigenous knowledge), which is developed outside of formal education systems and continuous adaption to changing environmental and socio-economic conditions, and which allows people to cope with immediate problems and develop pragmatic and contextually relevant solutions (Biggs and Matsaert, 2004; Smith, et al., 2014). Not limited to new principles, methods or technical breakthroughs made by farmers, furthermore, farmer innovation does not exclude new technologies introduced from the formal sector (e.g., research 
institutes or extension stations). Rather, it is focused on the role of farmer innovators (often treated narrowly as "early adopters") in initiating, testing and modifying them to ensure interfaces with the local technological, economic and social conditions. In short, farmer innovation denotes a process of technology learning, development and diffusion initiated and led by farmer innovators (Wu, 2003).

Farmer innovation, however, may not be able to diffuse widely beyond the location of innovation due to the nature of local knowledge, and the limitations of resources and social networks of farmer innovator(s). The interconnections with and participation from external resources and multiple stakeholders become a key for farmer innovation diffusion (Gareau, 2012; Wu and Zhang, 2013). The term farmer innovation system (FIS) is used to refer to such "social phenomena in which individuals and communities in a specific locality share and adapt local knowledge, integrate scientific knowledge, and develop better ways of managing resources and overcome local changes" (Sanginga, 2009). In reality, FIS may be called different names, such as farmer-led innovation systems (Wettasinha, et al., 2014), informal innovation systems (Cozzens and Sutz, 2012), demand-driven innovation (Kraemer-Mbula and Wamae, 2010) and grassroots innovation (Hossain, 2016; Korjonen-Kuusipuro, et al., 2017; Smith, et al., 2014).

The main actors in FIS are farmers although not all farmers are innovators. It is surrounded by supporting actors including formal institutions and organisations for agricultural policy, research and extension services, public or private agribusiness companies, and civil society organisations (QUNO, 2015: 18-19). By bringing together internal and external stakeholders, the FIS could help us to understand how farmer innovation happen through social network building (Wood et al., 2014; Wu and Pretty, 2004; Wu and Zhang, 2013), with the support of innovation intermediaries (Klerks and Leeuwis, 2009; Yang, et al., 2014), or partnership formation of multi-stakeholders (Kilelu, et al., 2013: 66).

There is an overlapping between the FIS and agricultural innovation system (AIS) as the latter is also emphasises on interconnectivity, multi-directional flow of knowledge and information between different stakeholders including farmers, the demand sides and innovative capacity building (Leeuwis and van den Ban 2004; Schut, et al., 2014). Mediating between farmers and external players (e.g., government agencies, formal research institutions and NGOs), according to Klerkx and Leeuwis (2009), innovation brokers play a crucial role in the innovation system in three aspects: demand articulation (in terms of technology, knowledge, funding, and policy), network formation (facilitation of linkages between relevant actors) and innovation process management (facilitating learning and cooperation in the innovation process). Following a similar line, Yang et al. (2014) find that farmer cooperatives (FC) in China as innovation intermediaries can provide corresponding services to link farmers to relevant actors, such as extension agencies, research institutes and supermarkets, and such functions cannot be overestimated due to the strong influence from government policies and limited participation of farmers in decision making. 
The importance of innovation mediation between farmers and external interventionists (government and non-government agencies) is further stressed by an actor-oriented approach. According to Long (2001), farmers as an important actor in rural development in the developing world, are not passive recipients of intervention but active participants "who process information and strategize in their deadlines with various actors as well as with outside institutions and personnel" (Long, 1992). This is not merely because the knowledge of farmers is a localised and such highly context-specific one that may have different meanings for different actors (Verschoor, 1992). Equally important is the multiplicity of social actors with "multiple realities" which "imply potential conflicting social and normal interests, and diverse and discontinuous configuration of knowledge", and which determines the multiple dimension of the government intervention (Long, 2001: 19).

By bringing different types of stakeholders together, innovation platforms (IPs) have been developed as a way to include the poor more explicitly as beneficiaries and as active participants in innovation processes. Based upon a comparative case study on the formation and functioning of IPs in livestock value chains in India and Mozambique, Swaans et al. (2014) suggest the importance of flexible planning process stimulating incremental change through innovation bundles (combinations of technological, organisational and institutional innovations), reflective learning (systematically challenging and constraining factors), and the vital role of innovation brokers in facilitating the innovation process. Despite many improvements compared to the generic innovation system approaches, which do not sufficiently consider the inclusion that inclusivity of the poor in the process of innovation, the IPs are still heavily dependent upon external inputs or initiative, with an ignorance or underestimate of the internal process of technology learning, improvement and invention within rural communities.

With respect to the role of supporting actors in FIS, in particular, six areas are identified by QUNO (2015: 37), including: institutionalise support for farmer innovation; increase exposure of farmer innovative capacity; provide direct financial resources to farmers for on-farm research; facilitate knowledge sharing among geographically disparate farming communities, and so on. On the top of the outside participation in FIS, the term "institutional support" in the literature is used to emphasise the necessity of institutional arrangements and change norms, laws and procedures or "rules of the games" which could help researchers, scientists and policy makers to recognise the innovative capacity of farmers (Trupp, 1989; Leewis and van den Ban, 2004; Hounkonnou, et al., 2012). Along this line, nonetheless, modest progress has been reported with regards to institutionalising farmer-led research within research and development organisation (Wettasinha, et al., 2014). Whist the overwhelming attention is paid to the contribution from formal organisations such as civil society organisation, NGOs and farmer cooperatives (Wettasinha, et al., 2014; Yang, et al., 2014; QUNO, 2015; Waters-Bayer, et al., 2015), we know little about the role of government agencies in facilitating farmer innovation and collaboration between farmer innovators and other stakeholders from the outside. 
By bringing together two strands of literature, state intervention and farmer innovation system (FIS), we can draw following conclusions. Firstly, we have witnessed a paradigm shift departing from one-way, top-down state intervention, which gives more space for local knowledge and farmer innovation for bottom-up development. Secondly, whilst the concept of FIS provides a useful lens to obverse the role of supporting actors in facilitating farmer innovation, limited researches have done on the performances and potential of non-government agencies, including civil society organisations, NGOs and farmer cooperatives. By contrast, the specific role of government agencies in FIS is largely missed in current literature, including: whether or how can government agencies work together other stakeholders (e.g. non-government agencies and business partners), to provide support to farmer innovator(s)? And by what conditions is the government participation or intervention more likely successful, leading to a continuous and scaling-up of farmer innovation diffusion? This paper attempts to fill these knowledge gaps through two cases of SUT development and diffusion in China.

\section{Research design and fieldwork method}

For the purpose of this paper, the term government intervention here is broadly defined as all actions or policies taken by government agencies at various levels (from central to provincial to county), which influence the development and diffusion of farmer innovation across geographic boundaries. In particular, it denotes those means or measures, including: administrative, propaganda, financial subsidy, taken by government agencies which influence innovator's exploration, formatting and function of innovation platform, as well as the adoption or rejection of new technology by rural householders or users.

To understand the relationship between FIS and government intervention in the context of SUT development and diffusion, an empirical study has been taken by the first author of this paper and her team based at the Centre for Innovation and Entrepreneurship Studies (CIES) at the Tianjin University of Finance and Economics (TUFE) since 2010. It contains two cases in different strands of SUT, semigasified stove for domestic cooking and heating and straw mushroom cultivation for commercial food production. We select two cases for continuous observation and repeated interviews for following reasons. Firstly, both involve government intervention: one is successful and the other a failure. Secondly, both cases can be traced back for long time (the 1980s and 1990s respectively) and (second) one is still alive until now. Thirdly, the scope of both cases is beyond local (county) and provincial boundaries in terms of the diffusion of technological information and innovative products.

Both cases began from the screening of public media reports via newspapers or online information on farmer innovation and entrepreneurship, a part of the CIES programme to create a farmer innovation database. It has resulted in many field trips to the locations of both the origin of innovation (counties of the innovators) and other places of similar innovation explorations or application of the 
above innovation in Hebei (Huanghua and Handan Municipalities) and Shanxi (Changzhi Municipal) for the first case; Hunan (Changde Municipality), and Jiangsu (Nantong Municipality) for the second case. Alongside participatory observation for innovation environments and local economies, we conducted in-depth interviews with farmer innovators, their associates, business entrepreneurs, and government officials. It was followed by our repeated visits to learn about the latest progress in technological advances, and comments or feedback from rural community leaders and members who were involved in innovation diffusion projects. Nonetheless, we invited innovators to visit Tianjin University of Finance and Economics to share their experience with researchers and students ${ }^{1}$. The details of our research methodology and age profiles of interviewees are summarised in Tables 1 and 2 respectively while the list of research questions is in the Appendix.

Table 1 Summary of research methods employed in two cases

\begin{tabular}{|l|c|c|}
\hline \multicolumn{1}{|c|}{ Item } & Case 1 & Case 2 \\
\hline Name of technology & Semi-gasified stove & Straw mushroom cultivation \\
\hline Beginning of farmer innovation & Early of the 1980s & Mid of the 1990s \\
\hline Year of trips to location of innovator & 2010,2012 & 2011,2013 \\
\hline Year (s) of innovator visits to TUFE & 2013,2015 & 2014 \\
\hline Interviews with innovator (times) & 5 & 3 \\
\hline Interviews with entrepreneurs (person) & 3 & 4 \\
\hline with government officials (person) & 3 & 10 \\
\hline with rural users/leaders (person) & 20 & 3 \\
\hline
\end{tabular}

Table 2 Age profiles of interviewees by case and role in innovation

\begin{tabular}{|c|c|c|c|c|c|c|}
\hline Case & Role & Gender & No. & $<=30$ & $31-50$ & $>50$ \\
\hline \multirow[t]{5}{*}{ Semi-gasified stove } & Innovator & Male & 1 & & 1 & \\
\hline & Entrepreneur & Male & 3 & & 2 & 1 \\
\hline & Government officials & Male & 3 & 1 & 1 & 1 \\
\hline & Rural people & Male & 12 & 2 & 4 & 6 \\
\hline & & Female & 8 & 1 & 3 & 4 \\
\hline \multirow[t]{5}{*}{ Straw mushroom } & Innovator & Male & 1 & & 1 & \\
\hline & Entrepreneur & Male & 3 & & 2 & 1 \\
\hline & Government officials & Male & 4 & & 2 & 2 \\
\hline & Rural people & Male & 6 & 2 & 3 & 1 \\
\hline & & Female & 4 & 1 & 3 & 1 \\
\hline
\end{tabular}

${ }^{1}$ Working together with the National Innovation Function of India and the Centre for Innovation and Entrepreneurship of Tianjin University of Finance and Economics, Mr. Liu Yongquan and Mr. Yu Bo, two farmer innovators of the first case were invited to visit India in 2015. 
Fieldwork experiences above allow us to develop a framework to analyse empirical data and reveal the influence of government intervention. Bearing in mind the nature of on-going development of both technologies and government policies in the field, we assume that the following key elements influence the effects of government intervention:

- SUT system. The term SUT here refers to all technical principles, conditions, measures and methods, which support core technological principles and devices for better use of local straw resources. For this paper, SUT includes two technologies:1) semi-gasified stove which is associated with briquetting, collecting, drying and storing straw technologies or devices; and, 2) straw mushroom cultivation (SMC). The term SUT system here lays emphasis on the nature of interconnections between core technology and local support technologies, which can be measured in three aspects: appropriateness (fitting local ecological, economic and cultural environments), maturity (reliability, durability, affordability), and interfaces (with local skills and production or infrastructure conditions).

- Innovator's exploration. An innovator here is one or a group of persons who are leading local technological learning, testing, modification or reinvention to ensure the appropriation of a new technology to local environments. Depending upon the maturity of new technology and other factors, the process of innovator's exploration may begin from personal curiosity without any external support.

- Innovation platform (IP) here refers to any channel, means, or organisational arrangements which provide vital help or support for innovator(s) to disseminate new ideas, technologies, and products widely, and to communicate with and have access to vital resources and opportunities. For FIS, the IP is an important bridge for innovators to link with government agencies and relevant stakeholders to gain their support. Taking into account various costs (materials, time and energy), expected economic return, and many risks or uncertainties in both technology and the market, IP plays a key role in facilitating the exchange and mutual benefits between innovators and interested users. IPs could be traditional family support networking, informal partnerships with local entrepreneurs or agribusiness companies, or formal farmer cooperative.

- Rural response here denotes the attitudes and decision making of rural householders or users in adopting or rejecting the new technology. In addition to the maturity of new technology itself, many factors may influence rural response, such as trust in new technology and innovator(s), the strength of government intervention, costs and benefits, etc. In relation to the theme of this paper, we would like to pinpoint two changes in rural China over the decade: 1) large-scale rural-urban migration, leading to a decline of free labour for collecting and transporting straw 
from farmland to family yards, and, 2) diversity of household energy consumption (e.g., electricity, coal, solar power) related to the increase of rural incomes. Nonetheless, rural response provides an objective reference for the success or failure of government intervention.

Bringing together the above elements, the development and diffusion of SUT can be viewed as a process of establishment and maintenance of a farmer innovation system in which farmer innovator(s), government agencies, innovation platforms (business entrepreneurs), rural householders or users are interconnected and interacted with, leading to recognising, evaluating and making decisions for either adopting or rejecting the new technology. A logical chart for the links between variables and foci of this paper (in solid lines) is illustrated in Figure 1.

Figure 1 Government intervention for SUT development and diffusion

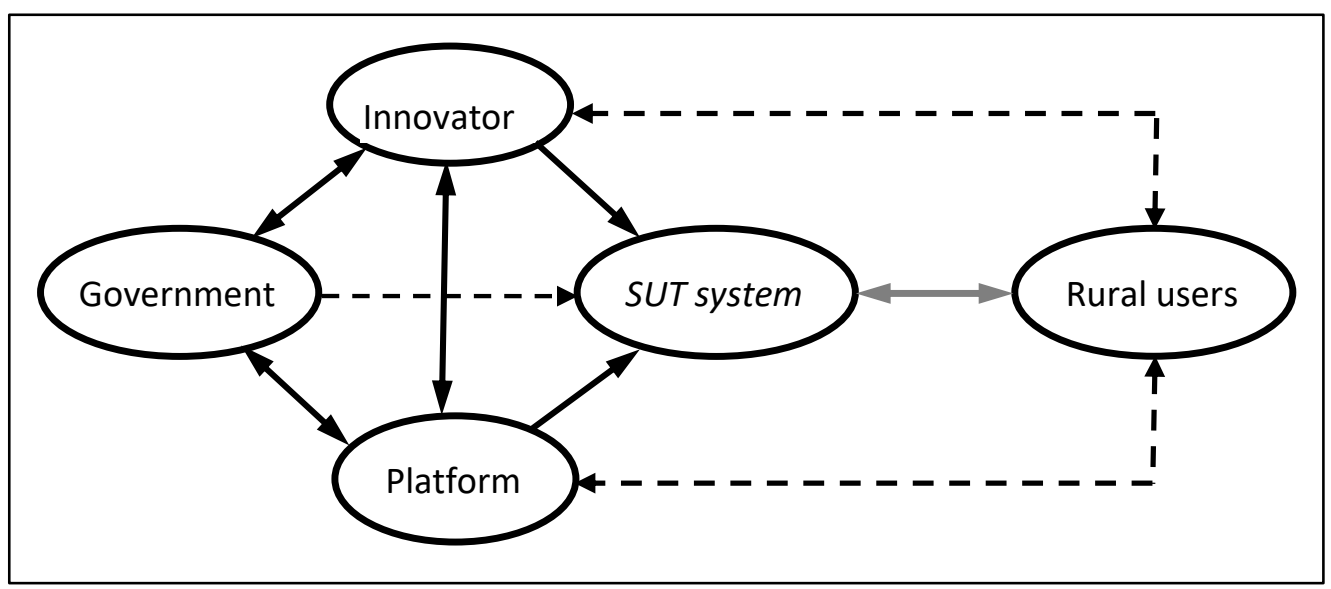

Notes: The solid line stands for communication/interaction (two ways) or influence (one way); The broken line stands for communication/interaction which is less discussed in this paper; The grey line stands for acceptance or rejection of technology by rural users.

\section{Narratives of two SUT cases}

Two cases below illustrate the uneven process of straw utilisation technology (SUT) development and diffusion initiated by farmer innovator(s), as well as the interaction between farmer innovator(s), government agencies, agribusiness entrepreneurs and other stakeholders.

\subsection{Semi-gasified stove for cooking and heating}

Mr. Liu Yongquan, a farmer in Huanhua Municipality of Hebei Province, initially focused on straw gasifier, later changed to semi-gasifier. The strategy of innovation diffusion can be summarised as government intermediation between innovator and enterprises, and financial subsidies for sales of the innovative products. 
The story began in the late 1990s when a laboratory in Tsinghua University developed a straw gasification technology, in which straw could be gasified and burned directly. Influenced by public media and advertisements, Mr. Liu, a farmer specialised in vegetable production, went to Beijing to attend an exhibition of the new invention and brought a brochure of the device. Like so many followers of this technology, Mr. Liu tried to imitate this invention in his home, and found it did nott work at all ${ }^{2}$. This led to his long journey in modification and improvement of the gasified stove.

Having been to so many unsuccessful experiments and modifications, Mr. Liu took a leading position in gasified stove design for rural families at the beginning of the 2000s. With the help from a local university graduate, he published his progress and devices via the internet in 2004, which attracted an inflow of businessmen across the country who went to Huanghua to purchase his stoves ${ }^{3}$. This phenomenon soon drew the attention of the Municipal Bureau of Agriculture which was in charge of promoting new and cleaner energy. Mr. Zhao, the Director of the Agricultural Bureau at that time, provided a donation of 1,000 yuan to encourage Mr. Liu to continue his innovative exploration. Meanwhile, Director Zhao invited Mr. Liu to share his innovation story with local officials and rural people via various channels such as conferences, newspapers, radios and TV programmes.

Since then, helping Mr. Liu to improve the design of the gasified stove became a priority for the rural entrepreneurship programme undertaken by the Municipal Agricultural Bureau. The major measures included: searching for and inviting experts from formal sectors for consultation; bringing $\mathrm{Mr}$. Liu to participate in relevant exhibitions, study tours, training courses and competitions organised by provincial government; developing and submitting project proposals to relevant funding sources at central and provincial governments. During the period, the Municipal Science and Technology Bureau helped Mr. Liu to apply and gain the award of a national patent for his gasified stove under the category of new utility model.

At the beginning of 2006, the Municipal Agriculture Bureau decided to promote the dissemination of 1000 gasified stoves in its rural areas under its provincial sponsored programme of "building a new countryside" by which each consumer (householder) who purchased the stove got a 200 yuan discount via government subsidies. Introduced and intermediated by the Agricultural Bureau, furthermore, Mr. Liu met and signed an agreement with Longxiang, a local company for joint improving, producing and disseminating the stoves to rural customers. Meanwhile, the government provided

\footnotetext{
${ }^{2}$ In the late $1990 \mathrm{~s}$, the technological development in straw gasified stove were popular in newspapers, magazines, and public media in which untrue information and false advertising had not only attracted so many people to this innovation but also caused economic loss to them due to the faultiness or immaturity of this technology. At that time for instance, if you enter the word "gasifier" for an internet search, you can find thousands of items with fraudulent information such as "easy to make money", "free training, expert guidance", "technology transfer with free training and guarantee of success", etc. The address of these companies, either within or near university campuses of Peking, Tsinghua or other famous universities, which gave an impression of the success and maturity of this technology.

${ }^{3}$ According to Mr. Liu, dealers came from more than 100 counties across the country to purchase his stoves, many of them become innovators in the improvement of the gasifier.
} 
financial support of 120,000 yuan to the company for purchasing and installing production equipment. Moreover, the government selected more than a dozen villages for the demonstration and promotion. By the end of that year, a total of 600 stoves were sold out. Not limited to Huanghua Municipal, Cangzhou City Government introduced by the Provincial government spent a total of 150,000 yuan to buy stoves from Mr. Liu and his Longxiang company, and sent them to the Three Gorges Dam region as a part of the government migration and resettlement project for these resettled householders in that region. The government intervention, however, did not last too long as most of householders stopped using stoves due to smoke, smell and other issues. Because so many users requested a refund, the project ended at a big loss for the Longxiang company, accounting for hundreds of thousands of yuan, leading to an end to cooperation with Mr. Liu. Afterwards, the government helped Mr. Liu to work with another company, which failed again due to the same reason: the immaturity of technology.

On account of the failed cooperation between Mr. Liu and Longxiang company, the boss of the latter was very angry. Below is his comment:

Boss of the Longxiang: "Mr. Liu was dishonest and didn't mention the defects of this technology" (gasified stove).

Mr. Liu replied: "I knew the defects when the government came and suggested cooperation with Longxiang for a diffusion project. I didn't mention them partly because I didn't want to lose this opportunity to earn money. However, neither did the government nor the company ask any questions about technological defects either, did they?"

Learning the lessons from the gasified stove, Mr. Liu decided to refocus his technological exploration to semi-gasified stove since 2008 with positive feedback. By 2009, his design became popular again in many neighbouring provinces including Liaoning, Shandong, Inner Mongolia and so on where the distributors followed the business model of Mr. Liu in Huanghua Municipal and pursued local governments to provide financial subsides under the central government policy of "building a new countryside". In Huanghua Municipal, home of Mr. Liu, a total of 2,000 stoves were sold out in that year, of which only 500 were subsided by the government.

Having seen the success of semi-gasified stoves, Huanghua Municipal Government decided to promote it by offering subsidy for 10,000 stoves in $2010^{4}$. To implement the government plan, the Municipal Bureau of Agriculture once again intermediated between Mr. Liu and Mr. Sun, a local entrepreneur for joint production and distribution, and assigned 20 villages cross the Municipal for

\footnotetext{
${ }^{4}$ Main motivations for the government to promote Mr. Liu's semi-gasifier were as follows: Firstly, the new model of semigasified stove was more mature than gasified one, which had been recognized widely within Hebei Province and beyond. Secondly, Mr. Liu's innovation falled into the priority areas of the national industrial development policies so that it was easy for Huanhua Municipal to gain funding from the Provincial government for sale subsides. Thirdly, Huanghua Municipal Government was carrying out a "Building a New Countryside" programme in 2007 to improve rural environments including "dirty, massive, poor hygiene standards" wherein semi-gasified stoves could contribute significantly.
} 
demonstration and promotion. At the beginning of 2012, Mr. Sun's firm incurred losses due to the decline of the market for stoves and also capital chain break, resulting in the end of cooperation with Mr Liu. Consequently, Mr. Liu gave up his innovation exploration at home and moved to Liaoning province to take an unrelated job in a company.

Despite strong support from local government in multiple aspects, the failure of Mr. Liu's innovation diffusion can be attributed to many factors. For the gasified stove, it was rooted in the fact that gasification of straw for cooking and heating did not work well for rural families no matter how much effort was made by Mr. Liu and what support he received from local government, business companies and external professionals. Some lessons should be learnt from public media and publicity sector, which failed to provide a balanced account on both positive and negative sides of the new technology. Given the immaturity of the technology, in particular, the failure of government intervention cannot be ignored not only because the government made wrong adjustment, leading to big losses for two local enterprises, but also because there was hardly any robust procedure for government decision making or the government decision was not preceded by any rigorous feasibility studies.

When it comes to the semi-gasified stove, one of major factors responsible for the failure of the government intervention has been the equal distribution of pilot villages across the Municipal without taking into account the differences among the villages and the cost of transportation and collection of straw. In addition, the diffusion of semi-gasification furnace technology could not be successful without other conditions to be met including: costs and mechanisms for the collection and storage of straw; production and service networking surrounding briquettes, and so on. The above issues are far beyond the capacity of individual innovators or commercial companies. Perhaps what was called for from the State was to visualise these problems in a systemic perspective and bring together different stakeholders with a comprehensive strategy for complementary activities needed for the diffusion of semi-gasified stove.

It is worthwhile to note that the mode of government intervention should vary with the nature of the project. In a similar case of winter greenhouses for vegetable production (Wu and Zhang, 2013), the intervention by the Shouguang government in Shandong province in the early 1990s was very successful partly because the greenhouse technology was relatively simple and also the market demand for products (vegetables in winter-spring seasons) was strong. This is different from the case of Mr. Liu's semi-gasified stove in which the market demand was not so strong given the availability of cheap substitutes like coal on account of its excess supply. Compared to coal, the straw briquetting fire has low heat, not easy to control, and also there was no continuous supply of briquettes along with other technical issues (e.g. tar and odor). 


\subsection{Straw mushroom cultivation (SMC)}

In the early 1980s, Mr. Gao Dedian, a farmer from Hunan Province entered the field of edible fungi, leading to his research and development of straw mushroom cultivation (SMC). Since then, he has not only led its technological development and improvement, but also its innovation diffusion through the joint design and implementation of training programmes with government agencies.

In $1984 \mathrm{Mr}$. Gao was successful in the invention of the "straw mushroom", and began to produce mushrooms in his own greenhouse for sale. His innovation was soon noticed by a township leader, resulting in a wider dissemination and promotion of his invention by local media. Thereafter, local government agencies, including District Science and Technology Bureau, Agriculture Bureau, encouraged and helped Mr. Gao to apply for a patent and also establish a mushroom workshop, Hongyun Mushroom Factory for scaling up of mushroom production. Based upon the workshop, he worked with the government agency to run a joint training course for the dissemination of his technology since 1996 which lasted for six years at the scale of dozens of trainees per month. It played an important role in disseminating his technology widely as trainees came from all over the country ${ }^{5}$.

The government's involvement in Mr. Gao's training course was important as it provided a guarantee for those interested regarding the quality and reliability of the innovation. The income from the training course, paid for by the participants, was shared between Mr. Gao and Office of Technology Management of the Municipal Agricultural Bureau at the ratio of $80 \%$ and $20 \%$ respectively. The revenue thus received by the government was reinvested for the promotion of the training course. Later a local research institute, Hunan Province Cotton Institute, approached Mr. Gao for cooperation, leading to another joint training course for disseminating his SMC technology, which lasted for another two years. In practice, the Institute through its Edible Fungus Plant near Hongyun Village (Mr. Gao's home) was responsible for recruiting trainees while Mr. Gao was responsible for running a training course. The training income was equally shared between the Institute and Mr. Gao.

In 2002, local government (Dingcheng District Bureau of Agriculture) recommended Mr. Gao to set up a Dingcheng Mushroom Cultivation Institute ${ }^{6}$, with the mission to diffuse SMC technology via the local technology market. Consequently, Mr. Gao's Institute was made eligible to apply for government funding available from different Departments, resulting in the inflow of tens of thousands of yuan for Mr. Gao and his teammates to develop SMC technology and also for providing free training courses and consultation for local farmers. To promote the diffusion of SMC on a larger scale, Changde

\footnotetext{
${ }^{5}$ Since he was awarded the national patent in 2002, Mr. Gao's invention was reported and promoted by official media at national level including: CCTV Channel II and People's Daily.

${ }^{6}$ The Institute was a subordinate to Dingcheng District Rural Technology Market Management Office, a part of the District Bureau of Science and Technology whose responsibility was to promote and regulate the trade of agricultural products through the government's "science and technology trade license" scheme.
} 
Municipal government decided to establish a Mushroom Research Association and Mr. Gao was appointed as the Vice Chair of the society in 2008.

As the Vice Chair of Changde Mushroom Research Association, Mr. Gao played a leading role in running a training programme for local farmers to promote and disseminate his innovation across the Municipal, to which the government provided a funding of 50,000 yuan per year. Recognising his achievements in innovation diffusion, Mr. Gao has been awarded a number of honours by government agencies at various levels. They came in different names such as "Innovation Demonstration Household", "Outstanding Inventor", "Farmer Scientist", "Municipal Science and Technology Progress Award". Mr. Gao cherishes these honours and considers that he is engaged in the same work as an expert or professor in the formal sector.

Based upon the successful diffusion of SMC in the past, Mr. Gao has been appointed an expert for government training projects. For example, in 2012, he was invited to involve in the "Sunshine Project", which provided training opportunities for disabled people in Dingcheng District to learn edible fungus technology. It was carried out by more than 30 townships benefitting about 30 individuals from each township ${ }^{7}$. Further joining with Mr. Gao Dingcheng District Science and Technology Bureau held regular training courses (quarterly each year) for farmers to promote mushroom production benefiting around 1,000 people each year. With permission from Mr. Gao, the local government uses his training content for distance education.

In 2012, Mr. Gao was assigned by Dingcheng District Government as an innovation advisor to Huayanxi Wild Vegetable Cooperative ${ }^{8}$. He used his knowledge and formula for successfully solving the problem of the fast spread of insects which might have led to a total loss of thousands mu mushroom land owned by the Cooperative9. During his stay in the Cooperative, Mr. Gao helped a local bamboo chopsticks factory to process the waste, leading to an invention of mushroom plantations by using waste of the bamboo chopsticks. Meanwhile, Mr. Gao introduced a new variant of the mushroom developed by a Research Institute in a nearby county.

In 2013, Mr. Gao was assigned by Changde Municipal Government as innovation advisor (he was one of the two advisors selected from local farmer innovators) to attend a project on the mushroom

\footnotetext{
${ }^{7}$ To deliver the Sunshine project, government provided financial subsides to Mr. Gao based upon the number of participants who successfully completed training courses at the rate of 200 yuan per household. Compared with the income, Mr. Gao treated such training for the disabled as an honor given by the government.

${ }^{8}$ Innovation advisor is a new position created by the Department of Science and Technology of the District Government to help local communities to sort out technical issues. The holders of this position are not paid from the government but gain bonuses from the project as the shareholders of technological inputs. Depending upon the actual contribution, the advisors can receive reward ranging from thousand to tens of thousands of yuan at the end of year.

${ }^{9}$ In addition to the pest formula, Mr. Gao released a lot of his innovation methods and know-how free of charge. For example, Mr. Gao had successfully developed a dwarf toon tree, like picking the same as the tea shoots, not only easy to pick but also with significantly higher output. Whilst the Agriculture Department contacted with him for the details of the innovation, he released it without any hesitation through a demonstration workshop.
} 
plant which was led by the Hunan Academy of Agricultural Sciences and funded by the Ministry of Science and Technology. This appointment is a mark of recognition by the local government for the achievements made by Mr. Gao. During the period, he developed close cooperation with a local company, namely, "Village People", to disseminate his technologies and know-how widely.

While we discussed the successful experience of government intervention, Mr. Zhang, Director of local Agricultural Business, offered the following comment:

"Mr. Gao's case, in my view, is only one of routing support to projects by local government. In other words, it is outside of government priority areas. This is because mushroom cultivation is a rather mature technology. For local government, we are more interested in providing strong support to those projects with the potential for technological breakthrough or economic development".

Mr. Zhang's comment seems to suggest that light government intervention, which leave more space for farmer innovator (s), could be one of the important factors leading to successful cooperation between Mr. Gao and government.

To conclude, the case of Mr. Gao's straw mushroom cultivation (SMC) can be viewed as one of successful government interventions ${ }^{10}$. Viewing farmer innovation as an important source for local economic and rural income growth, the government has provided various supports for farmer innovator(s) to explore new solutions for the challenges and barriers faced by the farmers. Once the effectiveness of the solutions is confirmed, the government worked together with innovators to run joint training courses to promote or diffuse new technologies widely. Light government intervention, which put farmer innovator(s) as the centre of agricultural innovation and diffusion, give more space for farmer innovator(s) to design or make decision for innovation and diffusion with the support of government.

\section{Discussion}

The two cases described in previous section can be summarised as two types of government intervention: government-led farmer innovation and government-facilitated farmer innovation. For the former, farmer innovation is encouraged and used by government agencies as the means to implement government projects. For the latter, in contrast, government agencies are participants and facilitators of farmer innovation diffusion, leading to the acceleration and scaling-up of the flows between innovators, innovation platforms (IPs), and local users.

\footnotetext{
${ }^{10}$ Many other cases are recorded in the book: Grassroots Innovations Across the Himalayas: Case Studies on People's Innovations from China and India", edited by Anil K. Gupta and Liyan Zhang, published by SRISTI Innovations, Ahmedabad, India, 2012.
} 
Compared to conventional state intervention via the model of the transfer of technology (ToT) or agricultural extension (shown as the broken line from government to rural users in Figure 1), a significant development can be found from both types of government intervention in terms of more space given to farmer innovator(s) who can work with other stakeholders (i.e. business partners or innovation platform in the bottom of Figure 1) for better use of local knowledge, resources and conditions to catch up with new opportunities related to the development and application of clean technology.

The two types of government intervention, however, have different characteristics and conditions of the success in practice. The first type, the government-led one, is characterised by strong intervention as the partnership between farmer innovators and government is skewed to the government side while the partnership between farmer innovator and business entrepreneurs (shown as two arrows of vertical line in Figure 1) is weak or fragile without government intermediation and fully support. Such a model could be successful and highly efficient if the conditions of maturity, appropriateness and interfaces of the new technology are met on the one hand, and needs of rural households for the new technology could be clearly defined and/or are homogenous on the other. In contrast, the second type, the government-facilitated one, may take a longer time to ensure learning from farmer innovator(s) and benefits to rural users. Such a type could be more sustainable because the whole process is initiated, controlled or dominated by farmer innovator(s) in terms of innovation exploration and network building (as the vertical line in Figure 1 strong). Compared with the government-led type, the strength of government intervention in government-facilitated type is much less, leaving more space for farmer innovators to design and control the process. Table 2 illustrate the two types of government intervention and their different characteristics.

Table 2 Summary of two types of government intervention in farmer innovation diffusion

\begin{tabular}{|c|c|c|}
\hline Item & $\begin{array}{l}\text { Government-led farmer } \\
\text { innovation }\end{array}$ & $\begin{array}{c}\text { Government facilitated farmer } \\
\text { innovation }\end{array}$ \\
\hline Empirical case & Semi-gasified stove & Straw mushroom cultivation \\
\hline $\begin{array}{l}\text { Role of farmer } \\
\text { innovator in SUT }\end{array}$ & $\begin{array}{l}\text { - leading technological tests and } \\
\text { improvement; } \\
\text { - online promotion to attract } \\
\text { public and traders nationwide }\end{array}$ & $\begin{array}{l}\text { - leading technological test and } \\
\text { improvement; } \\
\text { - successful diffusion within \& } \\
\text { nearby villages } \\
\text { - training course available for } \\
\text { interests nationwide }\end{array}$ \\
\hline $\begin{array}{l}\text { Technology system } \\
\text { and maturity }\end{array}$ & $\begin{array}{l}\text { - continuous improvement of the } \\
\text { appropriateness and reliability; } \\
\text { - deficits remaining compared } \\
\text { with coal; }\end{array}$ & $\begin{array}{l}\text { - matured and reliable for mushroom } \\
\text { farmers; } \\
\text { - variation and package of } \\
\text { technologies for full use of local } \\
\text { resources }\end{array}$ \\
\hline
\end{tabular}




\begin{tabular}{|c|c|c|}
\hline & $\begin{array}{l}\text { - other technologies, e.g. straw } \\
\text { collecting, storing and } \\
\text { briquetting, to be developed }\end{array}$ & \\
\hline $\begin{array}{l}\text { Motivation of } \\
\text { government } \\
\text { intervention }\end{array}$ & $\begin{array}{l}\text { - fit well to government } \\
\text { objectives in clean energy and } \\
\text { beautiful countryside; } \\
\text { - promote rural innovation and } \\
\text { entrepreneurship }\end{array}$ & $\begin{array}{l}\text { - support cash agriculture, rural } \\
\text { income growth; } \\
\text { - encourage agricultural innovation } \\
\text { diffusion } \\
\text { - promote farmer specialised } \\
\text { cooperatives }\end{array}$ \\
\hline $\begin{array}{l}\text { Styles of government } \\
\text { intervention }\end{array}$ & $\begin{array}{l}\text { - partnership with innovator for } \\
\text { patent and funding } \\
\text { applications; } \\
\text { - provide training opportunities } \\
\text { to innovator; } \\
\text { - farmer innovation diffusion } \\
\text { became a part of government } \\
\text { plan with short duration, large } \\
\text { amount of government } \\
\text { investment and subsides; } \\
\text { - intermediation with business } \\
\text { companies and consultants } \\
\text { from public institutes; } \\
\text { - promotion through propaganda } \\
\text { department and public medias }\end{array}$ & $\begin{array}{l}\text { - partnership with innovator for patent } \\
\text { and funding applications; } \\
\text { - joint design and promotion of } \\
\text { training courses for local farmers to } \\
\text { learn the technology regularly; } \\
\text { - establish a mushroom cultivation } \\
\text { association for innovator to } \\
\text { disseminate his innovation in large } \\
\text { scale; } \\
\text { - invite innovator as government } \\
\text { advisor for innovation diffusion }\end{array}$ \\
\hline $\begin{array}{l}\text { Innovation network } \\
\text { building (IP) }\end{array}$ & $\begin{array}{l}\text { - a virtual community with } \\
\text { interested traders nationwide; } \\
\text { - journalists involved in } \\
\text { promotion; } \\
\text { - business partnership through } \\
\text { government intermediation, } \\
\text { leading to big loss in short } \\
\text { duration }\end{array}$ & $\begin{array}{l}\text { - a network established with most of } \\
\text { trainees for information share and } \\
\text { technological exchange; } \\
\text { - partnership with government } \\
\text { agencies, research institute for joint } \\
\text { training courses and multiple gains }\end{array}$ \\
\hline $\begin{array}{l}\text { Results of } \\
\text { government } \\
\text { intervention }\end{array}$ & $\begin{array}{l}\text { - failure of interventions with } \\
\text { different reasons: the } 1^{\text {st }} \\
\text { caused by immature of } \\
\text { gasified technology, the } 2^{\text {nd }} \text { by } \\
\text { equal distribution of pilot } \\
\text { villages plus unreliable } \\
\text { briquetting machine; } \\
\text { - most of participatory } \\
\text { householders in sample } \\
\text { villages have changed to other } \\
\text { energy or use them as coal } \\
\text { stoves }\end{array}$ & $\begin{array}{l}\text { - many households within or nearby } \\
\text { Gao's village have become } \\
\text { mushroom farmers via his } \\
\text { cooperative; } \\
\text { - hundreds of thousands of farmers } \\
\text { within and beyond Changda } \\
\text { Municipality have benefited from } \\
\text { Gao's training courses or his } \\
\text { mushroom association's programme. }\end{array}$ \\
\hline $\begin{array}{l}\text { Continuity and } \\
\text { sustainability }\end{array}$ & $\begin{array}{l}\text { innovation exploration and } \\
\text { diffusion have been stopped } \\
\text { since } 2016 \text { due to the } \\
\text { depression of innovator who } \\
\text { suffered from unsuccessful } \\
\text { government intervention. }\end{array}$ & $\begin{array}{l}\text { - innovation exploration and diffusion } \\
\text { is continuous and increasing impact } \\
\text { through the establishment of } \\
\text { regional mushroom association and } \\
\text { close cooperation with governments } \\
\text { at district and prefecture levels. }\end{array}$ \\
\hline
\end{tabular}




\section{Conclusion}

In relation to the research questions posed in Section 1, a number of conclusions can be drawn as follows. Firstly, for sustainable use of agricultural resources and environmental improvement in rural China, this paper shows that farmer innovation is an important source of clean technology development. Equally important is farmer innovation system (FIS) in which farmer innovator (s) is centre for new technology learning and diffusion widely. Surrounding farmer innovator(s), our cases suggest that government is also one of important elements of the FIS, which brings together with other elements or conditions, including: SUT system, needs of rural householders, investment and return of commercial companies.

Secondly, the special role the government can play in the FIS is to bring together farmer innovators and key outside stakeholders to create and maintain an innovation platform (IP) for the access to and better use of public or private resources, and meet the needs of small-scale farmers in agricultural production and energy consumption. Without government participation and support, it would be difficult for grassroots innovators to develop and maintain this system to sustain their technical exploration and disseminate it to potential users widely, due to so many constrains from farmer innovators in terms of knowledge, resources and networking with external stakeholders.

Thirdly, the two cases presented in this paper illustrate the conditions of successful government intervention in establishment and development of FIS, ranging from the appropriateness and maturity of the technology and innovation platform (IP) to communication, interaction and cooperation between innovator(s), rural users and other stakeholders. Accordingly, two types of government intervention can be distinguished from each other: government-led farmer innovation and government-facilitated farmer innovation.

The aim of this research has been to analyse the role of government intervention in facilitating the farmers' innovation and diffusion. As is evident from the theoretical literature, the farmer innovation system consists of a number of supporting actors and the government is only one among them. The limitation of the present work is the focus on the relationship between government and farmer innovator(s), leaving out the interaction between government and other actors such as business partners and non-government agencies. We propose the exploration of a balanced account between farmer innovator(s), innovation platform and government intervention for future research. 


\section{References:}

Biggs, S., Matsaert, H., 2004.Strengthening poverty reduction programmes using an actor-oriented approach: Examples from natural resources innovation systems. Agr. Res. \& Ext, Network (AgREN) Paper, No. 134. Overseas Development Institute, London.

Cordoba, D., Jensen, K., 2014. The return of the state: Neo collectivism, agrarian politics and images of technological progress in the MAS era in Bolivia. J. Agr. Change. 14(4), 480-500.

Cozzens, S., Sutz, J., 2012. Innovation in informal settings: A research agenda. International Development Research Centre, Ottawa.

Delman, J., 1991. Agricultural Extension in Renshou County, China: A Case-Study of Bureaucratic Intervention for Agricultural Innovation and Change. Institute of East Asian Studies, Aarhus, Denmark.

Gareau, B.J., 2012. World apart: A social theoretical exploration of local networks, natural actors, and practitioners of rural development in southern Honduras. Sustainability, 4, 1596-1618.

Gupta, A.K. 2012 (eds). Grassroots Innovations Across the Himalayas: Case Studies on People's Innovations from China and India. SRISTI Innovations, Ahmedabad, India.

Han, C. P., 2012. Attitudes toward government responsibility for social services: Comparing urban and rural China. Int. J. of Public Opinion Res. 24 (4), 472-494.

Hong, J.L., Ren, L., Hong, J.M., Xu, C., 2016. Environmental impact assessment of corn straw utilization in China, J. Clean. Prod. 112, 1700-1708.

Hossain, M., 2016. Grassroots innovation: A systematic review of two decades of research, J. Clean. Prod. 137, 973-981.

Hounkonnou, D., Kossou, D., Kuyper, T.W., Leeuwis, C., Nederlof, E.S., Roling, N., Sakyi-Dawsoni, Q. Traoré, M., van Huis, A., 2012. An innovation system approach to institutional change: Smallholder development in West Africa. Agr. Sys. 108, 74-83.

Kilelu, C.W., Klerkx, L., Leeuwis, C., 2013.Unravelling the role of innovation platform in supporting co-evolution of innovation: Contributions and tensions in a smallholder dairy development programme. Agr. Sys. 181, 65-77

Klerkx, L.,Leeuwis, C., 2009. Establishment and embedding of innovation brokers at different innovation system levels: Insights from the Dutch agricultural sector. Tech. Forecasting and Soc. Chang 76(6), 849-860. 
Korionen-Kuusipuro, K., Hujjala, M., Patari, S., Bergman, J., Olkkonen, L., 2017. The emergence and diffusion of grassroots energy innovations: Building an interdisciplinary approach, J. Clean. Prod. $140,1156-1164$.

Kraemer-Mbula, E.,Wamae, W., 2010. Innovation and the Development Agenda, OECD/IDRC. Leeuwis, C., van den Ban, A., 2004.Communication for Rural Innovation: Rethinking Agricultural Extension. Blackwell Science, Oxford.

Li, T.M., 2005. "The State" and Failed Schemes. Amer. Anthrop. 107(3), 383-394.

Liu, H., Jian, G., Zhuang, H., Wang, K., 2008. Distribution, utilization structure and potential of biomass resources in rural China: With special references of crop residues. Renew. \& Sus. Energy Rev.12, 1402-1418.

Long, N. 1992. Introduction, in Long, N., and Long, A. (eds), Battlefields of Knowledge: The Interlocking of Theory and Practice in Social Research and Development, Routledge, Long and New York.

Long, N., 2001. Development Sociology: Actor perspectives, Routledge, London and New York.

Quaker United Nations Office (QUNO), 2015. Small-scale farmer innovation systems: A review of the current literature. QUNO, New York.

Sanginga, P.C., 2009. Innovation Africa: Enriching farmers' livelihoods, Earthscan, London.

Schut, M., Rodenburg, J. Klerkx, L. van Ast, A., Bastiaans, L., 2014. Systems approaches to innovation in crop protection: A systematic literature review. Crop Protection 56, 98-108.

Scott, J.C., 1998. Seeing like a State: How Certain Schemes to Improve the Human Condition Have Failed, Yale University Press, New Haven and London.

Sinton, J.E., Smith, K.R., Peabody, J.W., Yaping, L., Xiliang, Z., Edwards, R.,Quan, G., 2004. An assessment of programs to promote improved household stoves in China. En. for Sus. Devel. 8(3), $33-52$.

Smith, A., Fressoli, M., Thomas, H., 2014. Grassroots innovation movement: Challenges and contribution. J. of Clean. Prod. 63, 112-124.

State Energy Bureau of China (SEB), 2012. A guidance for the comprehensive utilisation of biomass resources in the period of "Twelve Five" Plan (2011-2015), government document in Chinese.

Swaans, K., Boogaard, B., Bendapud, R., Taye, H., Hendrickx, S., Klerkx, L. 2014. Operationalizing inclusive innovation: Lessons from innovation platforms in livestock value chains in India and Mozambique. Inn. and Dev. 4(2), 239-257. 
Sun, D.Q., Bai, J.F., Qiu, H.G., Cai, Y.Q., 2014. Impact of government subsidies on household biogas use in rural China. En. Pol. 73, 748-756.

Trupp, L..A., 1989. Legitmizing local knowledge: From displacement to empowerment for third world people. Agr. and Human Val. 6(3),13-24.

Verschoor, G., 1992. Identity, networks and space: New dimensions in the study of small-scale enterprise and commoditization, in Long, N., and Long, A. (eds), Battlefields of Knowledge: The Interlocking of Theory and Practice in Social Research and Development, Routledge, New York, pp. 171-188.

Wang, R., Jiang, Z., 2017. Energy consumption in China's rural areas: A study based on the village energy survey, J. Clean. Prod. 143, 452-461.

Wang, C.B., Zhang, Y.Q., Zhang, L.X., Pang, M.Y., 2016.Alternative policies to subsidize rural household biogas digesters. En. Pol. 93, 187-195.

Waters-Bayer, A., Krisjanson, P., Wettasinga, C., van Veldhuizen, L., Quiroga, G., Swaans, K., Douthwaite, B., 2015. Exploring the impact of farmer-led research supported by civil society organisations. Agr. \& Food Security 4:1-4.

Wettasinha, C., Water-Bayer, A. van Veldhuizen, L., Quiroga, G., Swaans, K. 2014. Study on impacts of farmer led research supported by civil society organisations, Penang, Malaysia: CGIAR Research Programme on Aquatic Agricultural Systems, Working Paper: AAS-2014-40.

Wood, B.A., Blair, H.T., Gray, D.T., Kemp, P.D., Kenyon, P.R., Morris, S.T., Sewell, A.M., 2014. Agricultural science in the wild, A social network analysis of farmer knowledge exchange. Plos One 9(8), 1-10.

Wu, B., 2003.Sustainable Development in Rural China: Farmer innovation and self-organisation in marginal areas. Routledge, London and New York.

Wu, B., Jules, P., 2004. Social connectedness in marginal rural China: The case of farmer innovation circles in Zhidan, north Shaanxi. Agr. and Human Val. 21(1), 81-92.

Wu, B., Zhang, L., 2013.Farmer innovation diffusion via network building: A case of winter greenhouse diffusion in China. Agr. and Human Val. 30(4), 341-351.

Yang, H. Klerkx, L., Leeuwis, C., 2014. Functions and limitations of farmer cooperatives as innovation intermediaries: Findings from China. Agr. Sys.127, 115-125.

Zhu, X.F., 2014. Mandate versus championship: Vertical government intervention and diffusion of innovation in public services in authoritarian China. Pub. Manag. Rev. 16(1), 117-139. 


\section{Appendix: List of interview questions}

- What is the innovation process, and what were main driving forces bringing you into this area? What were major difficulties or barriers against you during the process? How did you cope with those challenges?

- Who are main partners of your innovation and diffusion? What role did they play? How do you comment on their contribution to your project?

- What are view, attitude, position of government to farmer innovation, farmer innovators, their achievements and contributions to rural society? How do you think of government intervention?

- What is the role of government in innovation and diffusion? Could you give more details about how government involve or intervene the innovation diffusion? Why is government intervention necessary or important?

- In your view, is the government intervention successful or failed? Why do you say so, and what are the main reasons responsible for the success or failure? 